\title{
Resources Are Limited-the Creativity of People Not
}

\author{
Růžena Petríková ${ }^{1 *}$, Jiří Ciencala ${ }^{2}$ \\ 1,2 Vysoká škola podnikání, a.S., Michálkovická 1810, 71000 Ostrava-Slezská Ostrava
}

\section{BIOGRAPHICAL NOTES}

Růžena Petříková, prof, Ing, CSc., 1950. Vice-Chairman of Council of Quality of the Czech Republic; Chairman of Quality in Education Institution; Member of Scientific Board of Czech Technical University in Prague; Member of Body of Editors in the Czech Republic and Slovak Republic

Jiř́ Ciencala, doc, Ing. CSc, 1950. Associate Professor. VŠB - Technical University of Ostrava; 2004. Rector of Ostrava Business School. Innovation and Entrepreneurship; Corporate Strategy; Strategy Management; Leadership.

\section{KEYWORDS}

Creativity, quality, innovation, study, diagnostics, coaching, best practices.

\section{ABSTRACT}

Presented by post is one of the original forms of training programs with an emphasis on the area so-called the informal sharing of knowledge within the team. Specifically, the program of studies of creativity and innovation, that his unique comprehensive offer original solutions approaches to customers, services, processes, and products strongly supports the development of innovative processes, creation of innovative environment and hence the company's innovation culture. The aim of the study is to strengthen creativity, manage the technology and methods for enhancing creativity and finally to apply changes and innovation in practices.

\section{Introduction}

From many European, but today even the national experience shows that high value they have and will continue to have the organizations which demonstrate knowledge, creative and innovative potential of their employees. Also, it is already sufficiently well known fact only to that such organisations are worth investing.

It is already quite a known fact that if you want to move forward, to transform some of the processes, and through them to arouse interest in their production (product or service), then in the present communication, though no more than "polite" and making use of all available forms, is not enough. It is necessary to distinguish (in any case, not-imitate), to be able to respond quickly and surprise your customer offering, even "to shock".

Simply say, not letting the customers in no doubt that what you offer is exceptional, original, always with high added value for a specific customer. According to the famous economist Professor Zelený, a customer even becomes its own creator of innovation and the adoption or rejection of the bid depends on the quality of the business model that is based on this "innovation" offers to customers, generate revenue and cost structures, communication and relationships with customers, basic sources, key activities and processes. Coherence and integration of these attributes will then form 
a complex business model.

It's not only an innovative idea or a good business plan/model, with all the attributes that brings social benefits, after which all desire. They are, above all, creative people who can create this idea well and then inject into everyday life.

It is precisely the originality, creativity, which is a prerequisite for making innovations, as well as knowledge of the basic principles of development of business systems and processes and, ultimately, all of the currently available methodological tools of creation and innovation management. But it absolutely must get every person - the worker and must be suitably motivated.

What about reality? This shift/change often prevents the wrong set rules of the game and sometimes even the managers, who instead of supporting or encouraging only supervises the strict compliance with them, and thereby suppress all the creativity of its people on the team. And I think, it is already sufficiently known to ad 1) Manager, who himself is not creative, can never build a creative team, and by the words of our great entrepreneur T. Bata, by contrast, average managers are able to build only an average team ... ad 2) The creative talents of the team may be attracted only the climate, the atmosphere in which they can exercise their creativity. If not, the best, most talented leave, and this rare potential are lost forever.

\section{The Study of Creativity and Innovation in the Czech Republic - the Possibility of its Realization in the Czech Republic}

Possibilities for all those who are looking for a quick and relatively cheap solution, if any, improvements, changes or streamlining their activities and processes, for those who are looking for financial savings within their companies, or are faced with an ever-recurring errors in your projects, is to take advantage of the unique program of two-semesters study for the management of the development of creativity and innovation.

A key mission of the study of creativity and innovation ( $\mathrm{MCl}$ - Master of Creativity and Innovation) is to prepare the top specialists in the field of innovation and development of innovative potential of organizations. Degree program is designed for manufacturing companies, services and institutions of the public sphere. Just representation of participants from various fields contributes to the enrichment of the preview on the problem of the view of its own scope operating unencumbered by blindness.

The program will therefore focus on a few core areas using a variety of available, familiar and lesserknown management techniques, methods and tools, such as:

Tensile tests on biological tissue will be made in a in-vitro way (inactive tissue) [6] [7] [8]. Three samples of a sheep thoracic artery will enable us to carry out three tests.

- the development of personal and team creativity, based on the techniques of breaking down barriers, changes the angle of view on the issue, etc.,

- as well as training, relaxation and concentration with emphasis on anchoring the experiences and skills to apply their skills at any time,

an integral component of the course is training in the methods and techniques used for the analysis and solution to the problem.

The intention of the study is also each graduate was set to permanently standby creativity level, to have enough knowledge to use the acquired methods routinely, and he or she could concentrate on the solution when it is needed.

And should we briefly outline the study program? In the first module, the participants get acquainted with the theory of creativity, its concepts of management and psychological perspective, with the function of the brain, barriers of creativity and they can try out simple relaxation techniques. At the same time they pass an entry test, which will be repeated at the end of the study, to be able to assess the movement in the field of individual creativity. In the second part of the training area will be dedicated to the fundamental definition of problem analysis (SWOT analysis, force field analysis, 99 questions) as well as the use of analogies and associations for the search for a solution to the problem.

The second module focuses primarily on personal and team creativity, on its training through a wide range of individual and team tasks. Participants will begin to work on breaking down barriers, will be familiar with the principles of organizational structure to support creative and innovative environment. The development of individual and team creativity will also be trained through artistic disciplines - painting and work with the word in front of the camera. 
The third module focuses in particular on the area of innovative engineering. Participants are to understand concepts such as the innovative potential of the individual and the company, innovative marketing, innovative environment audit firms, etc. The fourth module is under the sign of method TRIZ/ ARIZ., which leads to a technical solution to the problem through the world's databases of patents. Of the other methods that lead to the productive solution to the problem is a trained synectics, which is a more complex combination of analogies and associations used to focus on the problem.

The fifth module is under the methods of leadership and corporate best practices database. Participants have the opportunity to try other techniques of concentration and deepen and freeze the ones that met previously.

The sixth module of lectures is a managerial decision making and coaching. The main topic of the module will become innovation, especially ways to tighten in the company ideas into successful commercial implementation stage. Participants are also, as an additional problem-solving techniques, learn how to draw and use mind maps.

The seventh module is designed for additional information from the area of innovative entrepreneurship; familiarize yourself with innovative decorations, etc. At the same time they will also focus on the application of creative methods in project management, other techniques and methods of creative problem solving, and finally to enhance relaxation and concentration techniques

The eighth module covers for more information about creating projects - what to watch out for, how to define the target, etc. In addition, participants learn about the system of innovative entrepreneurship in the Czech Republic, the technological profile of the Czech Republic with a practical example of where you can find practical information on the Internet about this topic. The last training day concludes repetition of synectics and participants also learns the results of benchmark test, which at the beginning of the study charted the entry level of creativity and measured at the end of their development.

As part of the creative diagnostics capabilities of the participants are evaluated in the following categories:

- Fluence (Fs) ... a measure of availability, speed and the ease with which there are new thoughts, ideas;

- Flexibility $(F s x)$... is a measure of flexibility, the ability to see things from different angles, to modify previously found ideas, thoughts, opinions, etc.; - Originality (Os) ... is associated with the ability to find new, unusual, unconventional, unique solutions;

- Elaborace (EC) ... is the ability to design, processing thoughts, and creative essay.

Output for the participant after passing a certification exam is a personal certificate to the manager of creativity and innovation. The certification test consists of thesis/dissertation, bearing the opponency of independent opinion, advocated by the commission, the test and open debate on the commission's chosen topic, presented during the course.

As already mentioned, part of the output is for the participant's evaluation of its progress in creativity - a comparison test with the test for final input.

\section{The Results of the Studies, Including Specific Examples of the Successful use of in Practice}

High topicality is subject to this model, in particular, in the current period, which may be a possible solution to the current crisis, just by changing the conception and execution of managerial roles, leading to innovation management business processes, often associated with a significant reduction in costs. All this, however, requires a measurable change of what managers do so far, it requires a fundamental change in their standard of professional conduct, and in particular by entirely new, often non-traditional and original professional competences.

This accredited study, particularly certified by a number of previous pilot workshops, courses and seminars, is guided by the basic idea that the normal solution in a competitive environment is not enough, because it is used by everyone. New training programmes therefore require a strong and strict focus on increasing flexibility, adaptability, ingenuity, creativity and initiative of people. Everyone could reach the innovation and the results. Aim of the study programme is to make graduates followed from creative ideas to the committed work and high performance significantly faster and more efficiently than relying on themselves. It is the express purpose of increasing efficiency and 
promoting the transfer of knowledge.

An important aspect is also the accent for socalled proactive non-formal education, which is due to the diversity of representation of participants in the study of the permanent part and, consequently, high added value for each specific graduate. Of course there is also a programme of acquisition of art to share with each other their knowledge - which in the vast majority of organizations not yet completely runs. In doing so, as we know from the experience of the most successful ones that culture, sharing, cooperation means a competitive advantage, which is often original, unique, which means that such an organisation do not imitate, but still able to respond very quickly to any new "non-model" situation, and often include changes to predict.

The first dozens of alumni clearly attests to the accuracy of this orientation, the following examples illustrate the use of the output of the study, both from the perspective of an employer, so from the perspective of participant in the study.

\subsection{Employer's view (CE0, Třinecké železárny, a.s.)}

Interest in training managerial staff is proof of the viability of each company where such workers rank key posts. And when the subject of interest is driven by the development of their creativity and innovation then the results are not long in coming. Not otherwise in the case of the five heads of operations and personnel director of Třinecké železárny, a. S., who are successful graduates of the $\mathrm{MCl}$ study. Their final thesis was an important contribution, both for their own personal development, as well as for the incorporated company.

For example, the solution to the lack of identification of the billets cast at the second continuous casting process using Ishikawa's diagram with the identification of eighteen different causes and determining the procedure for removing them is indicative of the ability of the author to apply theoretical knowledge in a creative way in such a complex process such as the production of steel.

Equally valuable and innovative knowledge work on the topic of "Solution of storage capacity for the coils of wire in TŽ, a. s.", where the author in addition to standard technical-technological and logistical aspects of the operation, deals also with the system approach to the internal factors of production.

Original approach was chosen by another au- thor, which teamed up with-a strategic approach with expert of technical and technological aditus. Performance was multiplied by the fact that it was a merger of two different corporate processes with different corporate cultures (after the acquisition). Only thanks to leadership qualities and a rich theoretical knowledge of the author managed to handle the problem in practice and in theory, with application to describe clearly the elements of project management, methods of 5S, optimizing workflows to change the powers and responsibilities of employees.

Another of the authors, in his work "came out" and found a solution to a known problem, when researchers and operators of the technology transfer old approaches and practices on the new device. In this particular case, when the author dealt with and resolved decreased downtime of rolling mills, continuous-fine rolling mills. In this particular case, it was the failure of automation technology. In figures this meant reducing downtime from 172 for 24 hours and cost savings in the tens of millions crowns. Courage, creativity and determination to prove that even reputable companies in the world have their weaknesses, and that we don't have to be ashamed of yourself for the work of our technicians, workers and managerial staff, has yielded benefits.

It's worth noting, as well as innovative features the work of the human resources director, who in any case did not remain in the grip of customs and traditions, and in measuring the effectiveness of appropriate forms of education and determination of its added value. Also interesting is his proposal--the concept of corporate academy, which has been now largely implemented.

Approach and deployment of these five employees, in some cases, students over the age of 50, clearly shows that even relatively older people can be justly and their contribution to the value of the company and its knowledge capital is huge. However, without the proper motivation, enthusiasm and faith in the company's mission would be carried out jointly the results of education were most likely to formal and people dissatisfied.

\subsection{Specific participant's view (executive head, TRANGO s.r.o.)}

It is good that becomes good practice, successful and modern companies include the requirement for the ability to be flexible and creative in the 
selection procedures. Fortunately, the days have been gone when already for admission to some of the places had to either be blond, tall and developed or control great world language. Expertise or ability to work wearing was irrelevant. Maybe that's why a number of such companies no longer exist and it's probably a good thing. In a healthy business climate is starting to outweigh the demand for expertise, flexibility and creativity.

A man, especially a teacher, should still learn. It was one of the many reasons why I got into the study by $\mathrm{MCl}$. I knew all this, what I have learned; I'll be able to pass on to my students, so that it was they who will be admitted to healthy and successful companies, because they will have a great ability to be flexible and creative. Another reason for my participation in the $\mathrm{MCl}$ was a team of tutors. Some I have the honour to know personally, and that the team was for me a sufficient guarantee of the highest quality. Last but not least, there was even an association of DTO that provides training and with whom I have been cooperating successfully and, ultimately, the environment in the foothills scenic landscape, where the study took place.

The program, which was focused not only on professional, often for me a completely new methods, but at the same time, as well as on the development of skills that one thinks that you do not have them. I never thought that I would be able to paint more than caricature head of cow, which my uncle taught me about 45 years ago. Within the study I painted, of course, for a helping of our lecturer-academic painter, a beautiful image. This success was enough to me that I have separated one room in our house from which it became a painting studio. Now I have here an easel and beautiful sofa, so I can, with a glass of good wine, enjoy my "works".

Exceptional seems to be working with a psychologist, an expert professional and a human being. He taught us to work "with yourself". His lessons were something quite extraordinary. He taught us to look to yourself, not only at each other. His approach to us was quite civil, friendly and open. I think that anyone who wanted to was really able to work on yourself, like never before. For years, I have been interested in Eastern philosophies and I practice thai-chi, so his lessons were really extraordinary opportunities to link their knowledge with new procedures.
Creative games that we had passed within the study, of course, I immediately tested on their students and I hope for them as they are, and, in particular, will be useful in life and their further professional career.

Although I am already "lady in years", I still love learning and the study, broken down into 8 seminars, enriched me significantly - new friends, new information, new experiences, new view, as well as a finding that there are still a lot of things that want to learn.

Graduation of this course is for me something like a wine-tasting dinner about a lot of great courses. Now I want to taste every dish in detail and to study all of the flavours and ingredients. Only then I do prepare, or add something of from my "cuisine" and my skill and to host them for more people

\section{Conclusions}

In the context of all above mentioned facts, and verified the facts, we can clearly sum up that our Czech managers and experts will not get along without creativity. To help them, as it can in other fields and disciplines, creative learning, creativity again to find, develop, train, fortify.

The development of knowledge, skills and its ability is about an incredibly rapid trend. To understand and master these aspects will not be easy. Enter and learn the essence of creativity, to know how to proceed in dealing with a variety of tasks and non-model situations, it often requires creative work as well as "remodel" invention into innovation - mainly it is adjusted to the study, which its assessment on the market soon finds, whether in the area of marketing and sales, logistics, in the organization of business processes and resources, etc. The traditional focus on "just" use of technical opportunities is not enough anymore.

\section{References and Notes}

[1] CIENCIALA J. Lidé v průmyslovém podniku. Praha: Professional Publishing, 2012. ISBN 978-80-7431-083-6

[2] JANKU゚ Š. Externí a interní marketingová komunikace $v$ podmínkách systému jakosti, dizertační práce, VŠB-TU Ostrava, květen 2009.

[3] PETŘíKOVÁ, R. Lidé v procesech řízení. Praha: Professional Publishing, 2007. ISBN 978-80-86-946-28-3 